\title{
Growth Performance and Feed Utilization of Clarias gariepinus (Teugels) Fed Different Dietary Levels of Soaked Bauhinia Monandra (Kutz) Seed Meal
}

\author{
B. I. Balogun ${ }^{1}$, S. J. Oniye ${ }^{2}$, J. Auta ${ }^{2}$, C. A. M. Lakpini ${ }^{3} \&$ F. O. Abeke ${ }^{3}$ \\ ${ }^{1}$ Department of Agricultural Education, Federal College of Education, Zaria, Nigeria \\ ${ }^{2}$ Department of Biological Sciences, Ahmadu Bello University, Zaria, Nigeria \\ ${ }^{3}$ National Animal Production Research Institute, Shika, Zaria, Nigeria \\ Correspondence: B. I. Balogun, Department of Agricultural Education, Federal College of Education, Zaria, P. M. \\ B. 1041, Nigeria. Tel: 234-805-889-0518. E-mail: bibalogun@yahoo.co.uk; balogunib@gmail.com
}

Received: July 26, 2015 Accepted: November 2, 2015 Online Published: January 19, 2016

doi:10.5539/jfr.v5n1p97 URL: http://dx.doi.org/10.5539/jfr.v5n1p97

\begin{abstract}
This study was conducted to evaluate the suitability of soaked Bauhinia monandra (Kutz) seed as alternative protein source for Clarias gariepinus and to determine cost of feed compounded. The proximate analysis of the diet (crude protein, crude fibre, ash, moisture content and lipid) were determined using AOAC (1980). Data for each parameter was subjected to one way analysis of variance (ANOVA) while means of various results were compared at 5\% level of significance. A preliminary study was conducted to determine the best processing method that reduced anti-nutrients to the minimum level without impairing nutrients composition. Boiled, toasted and soaked seeds were used. Bauhinia seeds soaked for 96 hours had least concentration of anti-nutrients. The experimental diets was formulated to contain soaked Bauhinia seed meal (SBSM) at levels of $25 \%, 50 \%$ and $75 \%$ inclusion (Diets 2, 3 and 4 respectively) with two diets acting as control (Diets 1 and 5). All diets were isonitrogenous ( $40 \%$ crude protein) and isocaloric $(3212 \mathrm{kcal} / \mathrm{kg})$. A 12 weeks feeding trial was conducted using juveniles which were randomly distributed into 12 improvised non-recirculatory and semi-flow through indoor plastic tanks $(52 \mathrm{~cm} \times 34 \mathrm{~cm} \times 33.5 \mathrm{~cm})$ at a stocking rate of 10 fish per tank and three (3) replicates per treatment. The experimental design was complete randomized. The fish were fed at $5 \%$ body weight, twice daily. Diets with higher inclusion levels of SBSM (diets 3 and 4) significantly depressed growth performance of fish. The variations observed in the Specific Growth Rate (SGR), Feed Conversion Ratio (FCR), Feed Efficiency Ratio (FER) and Protein Efficiency Ratio (PER) were associated with the anti-nutrients present in the diets, these parameters reduced with increasing levels of SBSM in the diets of fish. Based on the relative cost of diets per unit weight gain and protein gain, diet $2(25 \%$ SBSM $)$ was most economical. The results suggested that SBSM can be used to substitute up to $25 \%$ levels of dietary protein in C. gariepinus juveniles without significant reduction in growth.
\end{abstract}

Keywords: growth, feed utilization, Clarias gariepinus, Bauhinia monandra

\section{Introduction}

\subsection{Research Problems}

One of the major factors militating against fish farming in Africa, Nigeria inclusive has been high cost of fish feed ingredients (Dasuki et al., 2014). Animal protein sources which have become expensive, scarce and in high demand particularly fishmeal has been a major contributor to high cost of fish feed (Balogun, 2011). Omitoyin (2007) reported that a lot of fish farmers in Nigeria depend on imported quality fish feeds which are usually expensive. An estimated 4,000 tons of quality fish feeds are imported into the country each year (AIFP, 2004). Utilization of such commercially formulated feeds increases the cost of production thereby reducing the profit margin of fish farmers. This ultimately translates to high cost of fish. For instance, feed represents a high proportion (50-80\%) of variable cost of production (Helfrich \& Craig, 2002).

There is therefore a pressing need to search for alternative cheap feed stuffs from unconventional sources to reduce cost (Odetola \& Eruvbetine, 2012 In: Olawepo et al., 2014). Seeds of leguminous origin provide a 
promising alternative (Olaniyi, 2009a \& b; Agbugui et al., 2011), one of such seeds is Bauhinia monandra (Kutz) which has potential for use in animal feed, fish inclusive, considering its crude protein content of $33.09 \%$ (Anhwange et al., 2004, 2005).

Against this backdrop that this research intends to explore the potentials of using graded levels of Bauhinia monandra as protein sources in the diet of juvenile Clarias gariepinus (Teugels).

\subsection{Justification}

Despite the fact that most seeds are readily available, their use in animal feed formulation is usually restricted, due to the presence of one or more endogenous compounds (such as saponins, tannin, phytate, oxalate, hydrogen cyanide etc) which decreases bioavailability of minerals and form complexes with digested food materials, thereby decreasing the absorption of nutrients in the intestine, hence reducing growth. These compounds (anti-nutrients) are present in feed stuffs of plant origin (Udoessien \& Ifon, 1992; Francis et al., 2001; Eyo, 2003; Ezekiel, 2004; Tamburawa, 2010). Non reduction or destruction of these components by processing normally have adverse effects on the nutritional value of the seeds (Udoessein \& Ifon, 1992). Bauhinia monandra plants are readily available and there is no competition between man and livestock for the seeds. The plants are found existing in most places as ornamental plants. Large quantities of Bauhinia monandra seeds are available during the fruiting season throughout the savannah region of Nigeria, but underutilized since they drop off to the ground from explosive dispersal from dehisced mature pods during the fruiting season. There is no documentation regarding the use of processed seed of B. monandra in compounding animal diet. However, information regarding the anti-metabolic constituent of Bauhinia seeds in relation to effects of processing is scanty.

Lack of comprehensive compositional data regarding essential nutrients and anti-nutrient compositions of the seed of several wild indigenous plants have limited the prospects of their utilization as livestock feed in Nigeria. Anhwange et al. $(2004,2005)$ reported that the percentage composition of proteins, lipids, carbohydrates and fibre in B. monandra were $33.09,28.70,21.45$ and 3.25 respectively. The amino acid composition in form of lysine, phenylalanine, leucine, isoleucine, methionine, valine, threonine and cysteine were $2.86,3.77,2.13,2.31$, $1.54,3.54,2.70$ and $1.11 \mathrm{~g} / 100 \mathrm{~g}$ protein respectively. The seed also contain $11.5 \mathrm{mg} / 100 \mathrm{~g}$ phytate, $0.32 \mathrm{mg} / 100 \mathrm{~g}$ hydrogen cyanide, $6.0 \%$ tannins and 2.05\% saponins which are anti-nutrients (Anhwange et al., 2004, 2005). Irrespective of the anti-nutrients Bauhinia seed offers tremendous potential as an attractive substitute for traditional protein sources in the diet of man and his livestock provided the anti-nutrients in the seed are adequately removed or reduced to a tolerable limit (Anhwange et al., 2004, 2005).

The choice of Clarias gariepinus among other fish species was due to the fact that the fish specie is found in nearly all fresh water bodies in Nigeria. They could be cultured in small water bodies and they also have attributes of being good converters of feed (FAO/IFAD, 1987). The fish are also cultured due to their tolerance to low dissolved oxygen, rapid growth rate, acceptability of a wide variety of food items, hardiness and disease resistance, ability to spawn in captivity and respond to induced breeding (Madu, 1995; Adesulu, 2001; Omitoyin, 2007). The fish is in high demand, highly priced, and with high economic returns either as fresh or smoked/dried (Banyigyi et al., 2001 a \&b).

The main thrust of this study was therefore, to compare the growth and survival of Clarias gariepinus juveniles fed unconventional Bauhinia Seed Meal as against a conventional commercial fish feed and to determine the suitability of Bauhinia Seed Meal in reducing the over-head cost of feed input.

\subsection{Aim and Objective}

The aim of this study is to use soaked Bauhinia seed meal as alternative protein sources to partially replace fish meal in the diet of Clarias gariepinus (Teugels) and to evaluate its effects on growth performance and feed utilization of the fish.

The specific objective of this work is to determine the growth response and feed utilization of Clarias gariepinus juveniles fed with graded dietary levels of processed Bauhinia seed meal.

\subsection{Hypothesis}

The hypothesis of this work states that Clarias gariepinus shows the same growth response and feed utilization when fed different levels of Bauhinia seed.

\subsection{Literature Review}

In the wild, fish obtain food naturally from aquatic environment; this food may be phytoplankton or zooplanktons, insects, seeds and small fish. However, under culture condition the natural feeds are not adequate for optimum growth therefore there is need for supplementary feeds to help fortify the naturally available diet 
with extra protein, carbohydrate, lipid, minerals and vitamin (Alatise \& Okoye, 1979; Lim \& Dominy, 1989).

The quality and quantity of feed used in fish culture are the major factors in determining profitability because feed represents the largest single expenditure in semi-intensive or intensive culture operations. Economical production depends on availability of least-cost nutritionally balanced diet (Lim \& Dominy, 1989). In Nigeria the high cost of feed input is a major problem of fish farmers in intensive and semi-intensive fish farming culture system (Ayinla, 1988; Fagbenro \& Davis, 2003). Nutrition is critical in fish production since it accounts for 40-80\% of production cost (Igeofagha, 1979; Eyo, 1990; New, 1993; Prendagast et al., 1994).

\section{Method}

\subsection{Experimental Fish}

Clarias gariepinus (Teugels) used in the experiment were obtained from Bagiwa farms along Funtua-Gusau road, Katsina State. Three hundred and fifty (350) Clarias juveniles were transported in two (50litres) containers between 0700 and $0800 \mathrm{hrs}$, to an outdoor concrete tank $(100 \mathrm{~cm} \times 150 \mathrm{~cm} \times 120 \mathrm{~cm})$ of the Department of Biological Sciences, A.B.U, Zaria, to acclimatize for 14days prior to feeding trials.

\subsection{Experimental Design}

During the 14 days acclimatization, fish were fed with $42 \%$ crude protein of a commercial feed (control diet) at $5 \%$ body weight twice daily. The water temperature, $\mathrm{pH}$ and dissolved oxygen (D.O) were monitored. Water in the outdoor concrete tank was replaced every two days. At the end of the acclimatization period, the fish were introduced into non-recirculatory but flow through indoor plastic tanks $(52 \mathrm{~cm} \times 34 \mathrm{~cm} \mathrm{x} 33.5 \mathrm{~cm})$. The experimental design was a complete randomized design. A total of one hundred and twenty (120) juvenile fish (mean weight $20 \pm 3 \mathrm{~g}$ ) were randomly distributed into the tanks at a stocking rate of 10 fish per tank. The twelve (12) tanks were assigned to four (4) treatments (control inclusive) at the rate of one treatment per experimental diet with three (3) replicates per treatment.

\subsection{Experimental Diet}

Raw Bauhinia seed samples were soaked in a bowl containing tap water at room temperature $\left(30 \pm 2^{0} \mathrm{C}\right)$ in seed to water ratio of $1: 10(\mathrm{w} / \mathrm{v})$ at the rate of $5 \mathrm{~kg}$ to 10 litres which completely submerged the seeds (Vadivel \& Pugalenthi, 2007). Dense ox-brown exudate was observed and was more pronounced as duration of soaking increased. The soaked seed samples were removed from the soaking water at the rate of $1 \mathrm{~kg}$ with a sieve at 24 , 48, 72 and 96 hours respectively and then spread separately on clean trays to sun-dry to a constant weight. The seed samples were then placed in appropriately labeled and tightly sealed polythene bags and stored in a cool dry place.

The best processing method (Bauhinia seed soaked for 96 hours) that reduced the concentration of anti-nutrients to the minimum level without impairing nutrient composition was used to prepare Bauhinia Seed Meal (SBSM96) which was used as protein source that progressively replaced fish meal on an isonitrogenous (40\% $\mathrm{CP}$ ) and isocaloric $(3212 \mathrm{Kcal} / \mathrm{Kg}$ ) basis at graded inclusion levels of $0 \%$ (Treatment 1$), 25 \%$ (Treatment 2 ), $50 \%$ (Treatment 3 ) and $75 \%$ (Treatment 4 ) in the ration formulated. A fifth ration comprised of the imported fish diet (Copens) which served as the reference diet. The diet with exclusively fish meal $(100 \%)$ and $0 \%$ soaked Bauhinia Seed Meal (SPSM96) served as control. The feed was formulated based on $40 \%$ crude protein (Table 1).

\subsection{Fish Sampling}

The individual weight of each fish was determined immediately after acclimatization using an electronic top-loading Mettler balance (model PB 3002). The total weight of fish per tank were recorded. Fish were weighed biweekly until the experiment terminated. The biweekly weighing allowed for adjustment of feeding levels for the subsequent weeks.

The gross composition of the experimental diets was based on Computer Linear Model which dictated the proportions of the variables in the diet. The information required for the computer formulation of least-cost feed as described by Lovell (1981) was adopted. These included: cost of feed ingredients, nutrient components of the feed, availability of feed materials, Essential Amino Acid (EAA), Essential Fatty Acids (EFA), phosphorus, calcium, digestible energy and protein ratio. 
Table 1. Gross composition of experimental diets (\%)

Dietary treatments

\begin{tabular}{|c|c|c|c|c|c|}
\hline $\begin{array}{l}\text { Ingredient Replacement level of } \\
\text { Soaked Bauhinia Seed Meal }\end{array}$ & $\begin{array}{l}\text { Diet } 1 \text { (Control) } \\
\text { Fishmeal } 100 \% \\
\text { SBSM }_{96}-0 \%\end{array}$ & $\begin{array}{l}\text { Diet } 2 \\
75 \% \\
25 \%\end{array}$ & $\begin{array}{l}\text { Diet } 3 \\
50 \% \\
50 \%\end{array}$ & $\begin{array}{l}\text { Diet } 2 \\
25 \% \\
75 \%\end{array}$ & $\begin{array}{l}\text { Diet } 5 \text { (reference) } \\
\text { (Copens) }\end{array}$ \\
\hline Maize & 25 & 18 & 3 & 3 & \\
\hline Soyacake & 12 & 21 & 31.65 & 37.25 & \\
\hline Wheat offal & 5.95 & 3.75 & 1 & - & \\
\hline Palm oil & 4.0 & 3.20 & 5.0 & 5.0 & \\
\hline Bone meal & 1 & 1 & 1 & 1 & \\
\hline Cassava & 2 & 2 & 2 & 2 & \\
\hline Fish meal & 44 & 33 & 22 & 11 & \\
\hline Bauhinia & 0 & 11 & 22 & 33 & \\
\hline Salt & 0.3 & 0.3 & 0.3 & 0.3 & \\
\hline Premix & 0.25 & 0.25 & 0.25 & 0.2 & \\
\hline DL-Methionine & 2.0 & 2.2 & 2.4 & 2.6 & \\
\hline Lysine & 3.5 & 4.0 & 4.4 & 4.8 & \\
\hline Total & 100 & 100 & 100 & 100 & \\
\hline \multicolumn{6}{|c|}{ Calculated nutrient composition analysis } \\
\hline Crude Protein \% & 40.00 & 40.00 & 40.00 & 40.00 & \\
\hline Metabolizing Energy (Kcal/Kg) & 3212 & 3208 & 32.09 & 3206 & \\
\hline Ether Extract \% & 4.69 & 4.50 & 4.88 & 5.01 & \\
\hline Crude Fibre \% & 2.52 & 2.59 & 2.81 & 3.11 & \\
\hline Calcium \% & 1.82 & 1.68 & 1.77 & 1.80 & \\
\hline Phosphorus \% & 1.27 & 1.17 & 1.01 & 1.12 & \\
\hline Lysine \% & 5.09 & 5.01 & 5.11 & 5.09 & \\
\hline DL-Methionine \% & 3.05 & 3.04 & 3.04 & 3.02 & \\
\hline Feed cost $\# / K g$ & 119.51 & 114.23 & 110.08 & 105.18 & 320 \\
\hline
\end{tabular}

Composition per 25kg of Bio premix is Vitamin A 4,000iu; Vitamin D 800,000iu; Vitamin E1 500mg; Niacin 10,000mg; Panthotenic acid 3,500mg; Biotin 15mg; Vitamin B 10mg; Folic acid 200mg; Chloric chloride 130,000mg; Manganese 60,000mg; Iron 15,000mg; Zinc 15,000mg; Copper 800mg; Iodine 400mg; Cobalt, 80mg; Selenium 400mg; Antioxidant 40,000mg.

All vitamins and minerals included in the composition met the NRC (1993) recommendations.

\subsection{Physicochemical Parameters of Water}

Water temperature and $\mathrm{pH}$ were measured weekly using HANNA instruments Model: HI-98129 and HI-987130 respectively, while dissolved oxygen (DO) was measured using test kit (HANNA instruments model: HI-3810). Unconsumed diets and faecal matter were siphoned off daily.

\subsection{Biochemical Analyses of Feed and Fish Sample}

Prior to the onset of the experiment, the proximate analysis of feed samples were determined using AOAC method (1980). On completion of the experiment, eviscerated whole carcasses of the fish in each treatment were collected, grounded into fine powder, subjected to proximate analysis. The AOAC (1980) method was used to determine moisture content, ash, lipid and crude fibre. Nitrogen/crude protein of the samples were determined as described by Pearson's (1976).

\subsection{Fish Feed and Feeding}

Fish were fed twice daily (manually) at $5 \%$ total biomass per treatment. 


\subsection{Growth Performance and Feed Utilization Parameters}

Mean body weight gain was calculated as described by Ogunji and Wirth (2001). Percentage live weight gain (PLWG) and specific growth rate (SGR) were determined as described by Somsueb and Boonyaratpalin (2001) and Tamburawa (2010) respectively. The feed conversion ratio (FCR), protein efficiency ratio (PER) and condition factor (K) were calculated as reported by Arunletaree and Moolthongnoi (2008), Vadivel and Pungalenthi (2007) and Madu et al. (2001) respectively. Economy of feed and weight gain and least cost analyses were calculated as presented by Madu and Akilo (2001) and Talabi (1986) respectively.

\subsection{Statistical Analysis}

Data obtained were pooled and subjected to one way analysis of variance (ANOVA) at $5 \%$ level of probability. Least Significant Difference (LSD) was used to separate means.

\section{Result}

\subsection{Physico-Chemical Parameters of Water}

The range of $\mathrm{pH}$, temperature and oxygen of water were $7.3-8.7,19.6-27.8^{\circ} \mathrm{C}$ and $3.4-6.8 \mathrm{mg} / 1$ respectively.

\subsection{Mean Proximate Composition of Soaked Bauhinia Seed Meal}

There was significant difference in the mean crude protein values in soaked Bauhinia seed meal diets. The crude protein content of diet $5(42.09 \%)$ was significantly higher $(\mathrm{P}<0.05)$ than diets $1,2,3$ and 4 which gave $40.00 \%$, $40.15 \%, 39.60 \%$, and $39.57 \%$ respectively (Table 2 ).

Table 2. Mean proximate composition of soaked Bauhinia seed meal diet

\begin{tabular}{llllll}
\hline \multicolumn{1}{c}{ Proximate } & \multicolumn{5}{c}{ Diets } \\
\cline { 2 - 5 } \multicolumn{1}{c}{ Composition } & 1 & 2 & 3 & 4 & 5 \\
\hline Dry matter & 93.89 & 93.04 & 93.77 & 93.94 & 93.79 \\
Ash & 4.90 & 4.08 & 4.38 & 3.89 & 5.85 \\
Crude protein & $40.00^{\mathrm{b}}$ & $40.15^{\mathrm{c}}$ & $39.60^{\mathrm{a}}$ & $39.57^{\mathrm{a}}$ & $42.09^{\mathrm{d}}$ \\
Crude lipid & 8.67 & 8.11 & 8.51 & 8.72 & 8.99 \\
Crude fibre & 2.16 & 4.09 & 4.14 & 4.15 & 2.50 \\
Nitrogen free extract & 38.16 & 36.61 & 37.14 & 37.61 & 34.36 \\
\hline SED \pm & 0.010 & 0.010 & 0.010 & 0.010 & 0.010 \\
\hline LSD $(\mathrm{P}<0.05)$ & 0.028 & 0.028 & 0.028 & 0.028 & 0.028 \\
\hline
\end{tabular}

Values with the same superscripts in the same column are not significantly different (P $>0.05)$ LSD.

\subsection{Growth Performance and Feed Utilization of Clarias Fed Soaked Bauhinia Seed Meal}

There was significant difference $(\mathrm{P}<0.05)$ in the mean final body weight $(\mathrm{MFBW})$ of fish fed the various diets. Diet 5 gave the highest MFBW (92.43g), followed by diet 1 while diet 4 gave the least $(56.5 \mathrm{~g})$. Fish fed the control and reference diets attained better weight gain than fish on diet 2, 3 and 4 (Table 3).

There was significant difference $(\mathrm{P}<0.05)$ in the percentage live weight gain $(\mathrm{PLWG})$ values between the diets, and similarly the mean weight gain (MWG). Diet 4 gave the least percentage PLWG (179.7\%) and least MWG (36.30\%). The highest PLWG values was obtained in diet 1 and 5 with values of $306.69 \mathrm{~g}$ and $370.08 \mathrm{~g}$ (Table 3).

There was significant difference $(\mathrm{P}<0.05)$ among fish fed the various diets with respect to specific growth rate. The best SGR results was obtained in fish fed the control diets (diet 1 and 5), while diet 4 had the least SGR value (Table 3).

The food conversion ratio $(\mathrm{FCR})$ values of the control and reference diets differed $(\mathrm{P}<0.05)$ from those of diets 2 , 3 and 4. Diets 2, 3 and 4 had the least FCR values (0.56) respectively. Therefore, the best result in terms of FCR was achieved in diets 2, 3 and 4 (Table 3).

The feed efficiency ratio (FER) values of fish fed the control and reference diets (1 and 5) differed significantly $(\mathrm{P}<0.05)$ from diets 2,3 and 4 . The best results were achieved in fish fed diets 2,3 and 4 with the highest values of FER (1.78) respectively, while diets 1 and 5 had the least FER values of 1.62 and 1.63 respectively (Table 3 ). 
Protein efficiency ratio (PER) results indicated that there was significant difference $(\mathrm{P}<0.05)$ among diets. Diets 3 and 4 differed significantly from the other diets. Diet 5 had the least PER value 3.88 followed by diet 1 (4.04) and diet 2 (4.44) respectively. Diet 3 and diet 4 gave the highest values of 4.51 and 4.50 respectively. Diets 3 and 4 gave the best PER results (Table 3 ).

The condition factor $(\mathrm{K})$ was significantly different $(\mathrm{P}<0.05)$ in the control and reference diets (diets 1 and 5$)$ compared to the rest of the diets (Table 3). Diet 4 had the least condition factor (K value) of 0.35 .

Mortality was highest in diet 4 followed by diet 3 with $80 \%$ PSR value. The highest fish survival values (PSR) of 96.67 and 93.33 were recorded in the control and reference diets.

Table 3. Growth performance and feed utilization of Juvenile Clarias gariepinus fed soaked Bauhinia seed meal for 84 days

\begin{tabular}{|c|c|c|c|c|c|c|c|c|c|}
\hline Trts & M.I.B.W & M.F.B.W & M.W.G & P.L.W.G & SGR & FCR & PER & K & PSR \\
\hline $\mathrm{T}_{1} 100 \%$ fishmeal $\mathrm{OSBSM}_{96}$ & 20.03 & $81.46^{\mathrm{d}}$ & $61.34^{\mathrm{d}}$ & $306.69^{\mathrm{d}}$ & $1.67^{\mathrm{d}}$ & $0.62^{b}$ & $4.04^{b}$ & $2.66^{\mathrm{d}}$ & 93.33 \\
\hline $\mathrm{T}_{2} 75 \%$ fishmeal $25 \% \mathrm{SBSM}_{96}$ & 20.30 & $78.50^{\mathrm{c}}$ & $58.20^{\mathrm{c}}$ & $286.69^{\mathrm{c}}$ & $1.61^{\mathrm{c}}$ & $0.56^{\mathrm{a}}$ & $4.44^{\mathrm{c}}$ & $0.70^{\mathrm{c}}$ & 83.33 \\
\hline $\mathrm{T}_{3} 50 \%$ fishmeal $50 \% \mathrm{SBSM}_{96}$ & 20.20 & $70.30^{\mathrm{d}}$ & $50.10^{\mathrm{b}}$ & $248.02^{\mathrm{b}}$ & $1.48^{\mathrm{b}}$ & $0.56^{\mathrm{a}}$ & $4.51^{\mathrm{d}}$ & $0.65^{\mathrm{b}}$ & 80.00 \\
\hline $\mathrm{T}_{4} 25 \%$ fishmeal $75 \% \mathrm{SBSM}_{96}$ & 20.20 & $56.50^{\mathrm{a}}$ & $36.30^{\mathrm{a}}$ & $179.70^{\mathrm{a}}$ & $1.22^{\mathrm{a}}$ & $0.56^{\mathrm{a}}$ & $4.50^{\mathrm{d}}$ & $0.35^{\mathrm{a}}$ & 70.00 \\
\hline $\mathrm{T}_{5} 100 \%$ Copens & 19.63 & $92.43^{\mathrm{e}}$ & $72.80^{\mathrm{e}}$ & $370.08^{\mathrm{e}}$ & $1.84^{\mathrm{e}}$ & $0.62^{\mathrm{b}}$ & $3.88^{\mathrm{a}}$ & $3.05^{\mathrm{e}}$ & 96.67 \\
\hline SED \pm & 0 & 0.0136 & 0.00316 & 0.0032 & 0.0126 & 0.0154 & 0.0154 & 0.01549 & \\
\hline $\operatorname{LSD}(\mathrm{P}<0.05)$ & 0NS & 0.0377 & 0.0087 & 0.0089 & 0.0351 & 0.0430 & 0.0430 & 0.0430 & \\
\hline
\end{tabular}

Values with the same superscripts in the same column are not significantly different $(\mathrm{P}>0.05)$ LSD. Superscript ${ }^{\text {a }}$ stands for the lowest value, while superscript ${ }^{e}$ stands for the highest value.

Values are means of three separate determinations.

\subsection{Least Cost Analysis, Economy of Weight Gain (EWG) and Economy of Protein Gain (EPG)}

Diet 4 had the least production cost of $\$ 105.18 / \mathrm{kg}$ followed by diet 3 with $\$ 110.08$ and diet 2 with $\$ 114.23$. The most expensive diets were the reference and control diets which had $\$ 320.00$ and $\$ 119.51 / \mathrm{kg}$ as production costs respectively (Table 4).

Diet 1 had the least and best EWG value of $\$ 1.91$ followed by diet 5 (reference diet) $100 \%$ copens (\$4.40) and diet 2 ( $\$ 5.39$ ) respectively. The most uneconomical diets were diet 3 ( $\$ 8.79)$ and diet 4 ( $\$ 8.64$ ) (Table 4).

In terms of economy of protein gain diet 1 (\$9.87) and diet 3 (\$9.90) were the most economical followed by diet 2 which had EPG value of $\$ 16.87$ (Table 4). The most uneconomical diet was diet 4 followed by diet 5 , the reference diet.

Table 4. Economy of weight gain and protein gain

\begin{tabular}{llllll}
\hline & Diet 1 & Diet 2 & Diet 3 & Diet 4 & Diet 5 \\
\hline Cost/ kg of experimental diet & 119.51 & 114.23 & 110.08 & 105.18 & 320.00 \\
Cost of feed \#/unit weight gain (g) & 1.91 & 5.39 & 8.79 & 8.64 & 4.40 \\
Cost of feed \#/unit protein gain (g) & 9.87 & 16.87 & 9.90 & 47.81 & 29.30 \\
\hline
\end{tabular}

\section{Discussion}

The mean proximate composition of the experimental diets obtained from the laboratory analysis is at variance with that of the computer calculated report of this same study which gave a $40 \% \mathrm{CP}$ for all the diets as desired implying that there was no significant difference $(\mathrm{P}>0.05)$ among the diets. However, between treatments there was significant difference $(\mathrm{P}<0.05)$ in mean proximate composition of experimental diets in relation to the $40 \%$ $\mathrm{CP}$, the experimental diets of this study ranged between $39.57 \%$ and $40.15 \%$ which is within the acceptable range of \pm 2 , standard variation in such types of prepared feeds (Agboola, 2004). According to Lall (1991) and Fasakin et al. (1998) linear programming offers considerable potential in the development of "least cost formulation" of fish feed. However, wide fluctuations occur in the composition of feeds ingredients due to 
seasonal and geographic variations, thus formulation should be modified accordingly since physical characteristics, milling and composition of the feed ingredients may have significant effect on the processing and quality of finished feed.

The crude lipid content of the diets ranged between 8.11 and $8.99 \%$, this value is within the acceptable standard lipid requirement of most tropical fishes (Adikwu, 2003).

The growth performance of the diets shows that the values of the mean weight gain (MWG) were positive and significant growth occurred in fish fed the reference diet $5(72.80 \mathrm{~g})$ and the control diet $1(61.38 \mathrm{~g})$ respectively and this was a reflection of the superiority of these diets over the experimental formulated diets. The implication of this is that fish fed $100 \%$ copens (the commercially formulated fish diet) gave the best result. The most superior diet in terms of MWG and PLWG among the experimental diets was diet $2(58.2 \mathrm{~g})$. The reduced values of MWG and PLWG observed with increased inclusion levels of the soaked Bauhinia seed meal diet $3(50.10 \mathrm{~g})$ and diet $4(36.3 \mathrm{~g})$ in fish were below expectation, in spite of the conducive physico-chemical parameters of water recorded. Generally high dietary levels of legumes have been found to be deleterious to the performance of the cultured fish (Phengnuam \& Suntornsuk, 2013; Liener, 2003). De-Silva and Gunasekera (1989) also indicated that poor performance of fish could be due to nutrient inbalance associated with plant protein source.

The high MWG, high PLWG, high SGR, high FER, high PER, high K, high PSR and low FCR values of fish fed diet 2 confers it with better advantages for growth and efficiency of feed utilization over the rest of the experimental formulated diets. This result agrees with the report of Olaniyi (2009 a\&b) who indicated that the higher the SGR and the smaller the FCR values, the better the feed quality. Adikwu (2003) also reported that a lower FCR value implies efficient feed utilization by fish.

Diet 2 (25\% Bauhinia seed) was the best diet that supported optimum growth of Clarias gariepinus juveniles. In terms of relative cost of feed per unit of biomass yield, diet $2(25 \%$ Bauhinia seed meal $)$ was the most economical. However, in terms of economy of protein gain diet $3(50 \%$ Bauhinia seed meal) was the most economical followed by diet 2, which was the cheapest. The decreased trend in growth performance and feed utilization of the experimental diets with increased inclusion levels of Bauhinia suggests that soaked Bauhinia seed meal at 96 hours have the potential of replacing fish meal provided it is utilized at low levels of inclusion in the feed of Clarias gariepinus to assist in bringing down the cost of fish feed.

Other processing methods of the seeds, such as fermentation and autoclaving and trial using fish species such as Cyprinus carpio and Oreochromis niloticus are recommended.

\section{Acknowledgement}

The authors are grateful to the Head, Biological Sciences Department, Ahmadu Bello University, Zaria for providing the facilities to carry out this study. Special appreciation also goes to our laboratory assistants for their technical support during the course of this study.

\section{References}

Adesulu, E. A. (2001). Pisciculture: Essential Production Information (1st Ed., p. 118). Eternal Communication Limited. Lagos, Nigeria.

Adikwu, I. A. (2003). A review of Aquaculture Nutrition in Aquaculture Development in Nigeria, In A. A. Eyo (Ed.), National workshop on fish feed development and feeding practices in Aquaculture, FISON, NIFR, FAO-NSPFS (pp. 31- 40).

Agboola, E. O. (2004). The Utilization of Castor Seed (Ricinus Communis L.) by Clarias gariepinus (Teugels) and Oreochromis niloticus (Trewavas) fingerlings. Unpublished M.Sc Thesis.

Agbugui, M. O., Oniye, S. J., Auta, J., \& Abeke, F. O. (2011). Growth performance and feed Utilization of Fingerlings of Clarias gariepinus (Teugels) Fed Processed Paulatia monandra (Kurz) Seed meal. Journal of Aquatic Science, 26(1), 12-31.

AIFP. (2004). Inventory of Feed Producers in Nigeria. Published by Aquaculture and Inland Fisheries Project. Annex II of the National Special Program for Food Security with the Aquaculture Development Program in all states and FCT Abuja, Nigeria (pp. 1-8).

Alatise, P. S., \& Okoye, F. C. (1979). The Effect of Tofu (Soybean) By-product as a replacement for fishmeal in the diet of Oreochromis niloticus fingerlings reared in a flow feed technology. In proceedings of the First Annual Conference, Fisheries Society of Nigeria (FISON), Lagos, (p. 107).

Anhwange, B. A, Ajibola, V. O., \& Oniye, S. J. (2004). Amino acid composition of the seeds of Moringa oleifera 
(Lam), Detarium microcarpun (Guill and Sperr) and Bauhinia monandra (Linn.). Chemclass Journal, 1, 9-13.

Anhwange, B. A, Ajibola, V. O., \& Oniye, S. J. (2005). Nutritional Potential of the Seeds of Bauhinia monandra (Linn). Journal of Food Technology, 3(2), 204-08.

AOAC. (1980). Official Methods of Analysis (13th Ed., pp. 291-858). Association of Official Analytical Chemists Washington DC.

Arunlertaree, C., \& Moolthongnoi, C. (2008). The use of fermented feather meal for replacement fish meal in the diet of Oreochromis niloticus. Environmental and Natural Resources Journal, 6(1), 13.

Ayinla, O. A. (1988). Nutrition and Reproductive Performance of C. gariepinus (Burchell 1822). Unpublished Ph.D. Thesis. University of Ibadan, Nigeria.

Balogun, B. I. (2011). Growth Performance and Feed Utilization of Clarias gariepinus (Teugels) Fed Different Dietary Levels of Soaked Bauhinia Monandra (Linn.) Seed Meal and Sun-Dried Locust Meal (Schistocerca gregaria). Unpublished Ph.D Thesis, Ahmadu Bello University, Zaria.

Banyigyi, H. A., Oniye, S. J., Balogun, J. K., \& Auta, J. (2001a). Feed utilization and growth of juvenile catfish (Clarias gariepinus) fed heat treated Bambara groundnut [Vigna susterranea Verde, (L)] meal. Journal of Tropical Biosciences, 1(1), 55-61.

Banyigyi, H. A., Balogun, J. K., Oniye, S. J., \& Auta, J. (2001b). Growth Performance and Feed Utilization of tilapia (Oreochromis niloticus) fed diets containing toasted Bambara groundnut (Vigna subterranean verde L.) Meal. Journal of Agriculture and Environment, 2(1), 121-127.

Dasuki, A., Dauda, A. B., \& Oshoke, J. O. (2014). Preliminary Investigation of Nutritional Quality of Senna obtusifolia for Potential Use in Fish Feed. American-Eurasian Journal of Sustainable Agriculture, 8(5), 94-98.

De-Silva, S. S., \& Gunasekera, R. M. (1989). Effect of dietary protein levels and amount of plant ingredient (Phaseolus aureus) incorporated into the diets on consumption, growth, performance and carcass composition in Oreochromis niloticus (L) fry. Journal of Aquaculture, 80, 121. http://dx.doi.org/10.1016/0044-8486(89)90278-0

Eyo, A. A. (1990). Some Aspect of utilization of Soybean meal by the Young Mudfish (Clarias anguillaris Linneaus). Unpublished Ph.D. Thesis Ahmadu Bello University, Zaria.

Eyo, A. A. (2003). Fundamental of Fish Nutrition and Diet Development. An Overview National Workshop. In Proceedings Fish Feed Development and Feeding Practices in Aquaculture - Nigeria (pp. 1-4). FAO-NSPTS.

Ezekiel, B. (2004). Evaluation of the Interaction of four Anti-Nutrients with Seven Mineral Elements Using Cottonseed Meal in Feed Formulation. Unpublished B.Sc. Thesis. Ahmadu Bello University, Zaria.

FAO/IFAD. (1987). Nigeria, Small-scale Fisheries Development Projects. Preparation Report. Annex 2., freshwater aquaculture development. Reports of the FAO/IFAD Cooperative programme investment centre no 77/87 IFNIR 23, 11 June 1987.

Fagbenro, O. A., \& Davis, S. J. (2003). Use of high water percentage of soy protein concentrate as fishmeal substitute in practical diets for African Catfish, (Clarias gariepinus) (Burchell) 1822: growth, feed utilization and digestibility. Journal of Applied Aquaculture, 16(1).

Fasakin, E. A., Balogun, A. M., Daramola, A. G., \& Olorunfemi, T. O. S. (1998). Utilization of water farm (Azolla africana) and Duckweed (Spirodela polynliza) in fish-feed formulation: A linear programming analysis Applied Tropical Agriculture, 3(2), 129-133.

Francis, G., Makkar, H. P. S., \& Becker, K. (2001). Antinutritional factors present in plant-derived alternate fish feed ingredients and their effects in fish. Aquaculture, 199, 197-227. http://dx.doi.org/10.1016/S0044-8486(01)00526-9

Helfrich, L. A., \& Craig, S. (2002). Understanding Fish Nutrition, Feeds and Feeding. Virginia Cooperative $\begin{array}{lllll}\text { Extension } & \text { Service } & \text { Publication. } & \text { Retrieved } & \text { from }\end{array}$ http://www.ext.vt.edu/pubs/fishries/420-256/420-256.html

Igeofagha, G. D. (1979). Profitability and fish culture. In: NIOMR. Occasional paper, 26, 8. 
Lall, S. P. (1991). Concepts in the formulation and preparation of a complete fish diet. (pp. 1-12). W.S.S. De Silva (ed.). Fish Nutrition research in Asia. Proceeding of the fourth Asian Fish Nutrition workshop. Asian fish Society Special Publication Asia Fisheries Society, Manila, Philippines 5:205p.

Liener, I. E. (2003). Plant Antinutritional Factors/Detoxification. Encyclopedia of Food Sciences and Nutrition (pp. 4587-4593). http://dx.doi.org/10.1016/B0-12-227055-X/00936-6

Lim, C., \& Dominy, W. (1989). Utilization of Plant Protein by Warm Water Fish American Soybean Association. USDA.ARS. Tropical Aquaculture Research Unit. The Oceanic Institute, Hawaii, 3AQ(15), 89-4.

Lovell, R.T. (1981). Escalating Feed Costs Require More Efficient Fish Feeding. Aquaculture Magazine, 7(15), 38.

Madu, C. T. (1995). The status of fish hatcheries and fish seed (fingerlings) production in Nigeria. In: Report of National Aquaculture Diagnostic Survey, National Institute for Fresh Water Fisheries Research (NIFFR), New Bussa, Nigeria (pp. 13-34).

Madu, C. T., \& Okilo, K. T. (2001). The use of live Maggot and Live Tilapia fry as Unconventional Diets. For Juvenilesof the Catfish Clarias anguillaris (L). In A. A. Eyo (ed). Fish Nutrition Fisheries Society of Nigeria (FISON) Sept., 2001. (pp. 72-80).

Madu, C. T., Basam, H. D., Isa, J., \& Okwego, C. (2001). Optimum Dietary Protein Level for Female Clarias anguillaris (L) broodstock In A. A. Eyo (ed). Fish Nutrition Fisheries Society of Nigeria (FISON) Sept., 2001 (pp. 45-51).

New, M. B. (1993). Feed and Feeding of Fish and Shrimp. ADCP/REP/87/26/FAO/UNDP, Rome.

Odetola, O. M., \& Eruvbetine, D. (2012). In Olawepo, K.D., Banjo, O.T., Jimoh, W.A., Fawole, W.O., Orisasona, O. \& Ojo-Daniel, A. H. (2014) Effect of Cooking and Roasting on Nutritional and Anti-Nutritional Factors in Kenaf (Hibiscus Cannabinus L.) Seed Meal. Food Science Quality Management, 24, 5.

Ogunji, J. O., \&Wirth, M. (2001). Alternative Protein Sources as Substitutes for Fishmeal in the Diet of Young Tilapia Oreochromis niloticus (Linn). The Israeli Journal of Aquaculture - Bamidgeh, 53, 34-43.

Olaniyi, C. O., Bini Omote, T., \& Gbadamosi, M. (2009a). Growth Performance and Nutrient Utilization of Clarias gariepnus fed processed Mucuna seed meal. In Proceeding 34 Annual Conference, Nigerian Society for Animal Production (pp. 222-225).

Olaniyi, C. O., Aderinola, O. A., Rafiu, T. A., Akande, T. O., \& Okunola, D. O. (2009b). Growth performance and nutrient utilization of Clarias gariepinus fed locust bean seed meal. In Proceedings of 14 Annual Conference, Animal Science Association of Nigeria (ASAN) (pp. 550-552).

Omitoyin, B. O. (2007). Introduction to Fish Farming in Nigeria (1st ed., p. 90). Ibadan University Press.

Pearson's, D. (1976). The Chemical Analysis of Foods (7th Ed., pp. 484-49). Church- hill Livingstone, Edinburgh.

Phengnuam, T., \& Suntornsuk, W. (2013). Detoxification and Anti-Nutrients reduction of Jatropha curcas seed cake by Bacillus Fermentation. Journal of Bioscience and Bioengineering, 115(2), 168-175. http://dx.doi.org/10.1016/j.jbiosc.2012.08.017

Prendergast, A. F., Higgs, D. A., Beams, D. M., Dosaugh, B. S., \& Deacon, G. (1994). Searching for substitute Canola. Northern Aquaculture, 10(3), 15-19.

Somsueb, P., \& Boonyaratpalin, M. (2001). Use of Feathermeal in Hybrid Clarias Catfish Feed (Clarias macrocephalus X Clarias gariepinus) Technical Paper No. 5/2001. Feed Quality Control and Development Division. Department of Fisheries Bangkok.

Talabi, S. O. (1986). Investment Prospects in Fish Feed Technology (pp. 224-231). Proceedings of Fish Society of Nigeria.

Tamburawa, M. S. (2010). Effect of Locustbean Seed Meal Diets on the Performance and Carcass Characteristics of Broiler Chickens A Ph.D Research Proposal, Presented at the Postgraduate Seminar Series of the Department of Animal Science, Faculty of Agriculture, Ahmadu Bello University (A.B.U.) Zaria (p. 15).

Udoessein, E. I., \& Ifon, E. T. (1992). Chemical Evaluation of some anti-nutritional constituents in four species of yam. Journal of Tropical Science, 32, 115-119.

Vadivel, V., \& Pugalenthi, M. (2007). Biological value and protein quality of raw and processed seeds of 
Mucuna pruriens var. utilis. Livestock Research for Rural Development, 19(7), 11.

\section{Copyrights}

Copyright for this article is retained by the author(s), with first publication rights granted to the journal.

This is an open-access article distributed under the terms and conditions of the Creative Commons Attribution license (http://creativecommons.org/licenses/by/3.0/). 